\title{
Pengaruh Ekstraksi Cara Basah dan Cara Kering Terhadap Aktivitas Antioksidan Ekstrak Cengkodok (Melastoma malabathricum L.)
} Effect of Wet and Dry Extraction to Antioxidant Activity of Cengkodok (Melastoma malabathricum L.) Extract

Encik Eko Rifkowaty, Adha Panca Wardanu

Program Studi Teknologi Pengolahan Hasil Perkebunan, Jurusan Teknologi Pertanian Politeknik Negeri Ketapang, Ketapang

Korespondensi dengan penulis (ap_wardhanu@yahoo.co.id)

Artikel ini dikirim pada tanggal 22 Desember 2015 dan dinyatakan diterima tanggal 26 Januari 2016. Artikel ini juga dipublikasi secara online melalui www.jatp.ift.or.id. Hak cipta dilindungi undang-undang. Dilarang diperbanyak untuk tujuan komersial.

Diproduksi oleh Indonesian Food Technologists ${ }^{\circledR}(2016$

\begin{abstract}
Abstrak
Penelitian ini secara umum bertujuan untuk mengetahui potensi tanaman Cengkodok (Melastoma malabathricum L) sebagai antioksidan alami, sedangkan tujuan khususnya adalah untuk untuk menentukan rendemen, total antosianin, dan ekstrak yang memiliki aktivitas antioksidan terbaik, serta menguji aktivitas antioksidan dan stabilitas warna dari aktivitas antioksidan yang terbaik. Ektraksi dilakukan dengan dua cara yaitu ekstraksi cara basah dan ekstraksi cara kering. Ekstraksi menggunakan pelarut etanol $70 \%$ dengan penambahan asam sitrat dengan perbandingan bahan dan pelarut 1:4. Selanjutnya dilakukan uji kestabilan antioksidan dan warnanya dari ekstrak yang memiliki aktivitas antioksidan terbaik, dan dilakukan ANAVA (Analisa Varian). Aktivitas antioksidan terbaik didapatkan dari perlakuan ekstraksi cara basah dengan rendemen 32,6142\%, total antosianin $33,3279 \mathrm{mg} / 100 \mathrm{gr}$ sampel, dan aktivitas antioksidan sebesar 95,2234\%. Kestabilan antioksidan dan warna antosianin semakin menurun seiring meningkatnya $\mathrm{pH}$, meningkatnya kadar gula, dan tingginya suhu pemanasan. Kemudian ANAVA menyatakan hasil bahwa pada kestabilan antioksidan berbeda nyata pada taraf $5 \%$ pada perlakuan $\mathrm{pH}$, kadar gula, dan suhu pemanasan.
\end{abstract}

\section{Kata kunci : Buah Cengkodok, Ekstraksi, Antioksidan, Aktivitas Antioksidan, Antosianin}

\begin{abstract}
This study was aimed to reveal the potency of weeds Cengkodok (Melastoma malabathricum $L$ ) as natural antioxidant source, while purpose specific for determine the extract yield, anthocyanin total, the best antioxidant activity possessed by an extract and its colour stability.. Procedure of extraction were conducted in two methods; wet extraction and dry (powder) extraction. Specifically, it was used $70 \%$ ethanol solvent and citric acid with the proportion between substance and solvent was 1:4. Furthermore, the test was done on the antioxidant stability and the colour of essence that has optimal antioxidant activity and then it was analyzed using ANAVA (Analysis of Variant). The optimal antioxidant activity was obtained from wet extraction treatment with yield $32,6142 \%$, anthocyanin total $33,3279 \mathrm{mg} / 100 \mathrm{Egr}$ of sample, and antioxidant activity was $95,2234 \%$. Antioxidant stability and anthocyanin decreased while $\mathrm{pH}$ and glucose was increased, and heating temperature was also increased. ANAVA showed that the antioxidant stability was totally different on the level of $5 \%$ on the treatment of $\mathrm{pH}$, glucose, and heating temperature.
\end{abstract}

Keywords: Cengkodok fruit, extraction, antioxidant, antioxidant activity

\section{Pendahuluan}

Antioksidan adalah senyawa kimia atau zat yang dapat menangkal atau mencegah reaksi oksidasi dari radikal bebas (Chang et al, 2002) dengan menyumbangkan satu atau lebih elektron kepada radikal bebas sehingga radikal bebas tersebut dapat diredam (Suhartono, 2002). Berdasarkan sumber perolehannya, ada 2 macam antioksidan, yaitu antioksidan alami dan antioksidan buatan (Hartanto, 2012).

Dalam industri pengolahan pangan, banyak produsen beralih ke penggunaan antioksidan sintetis seperti butylated hydroxyanisole (BHA), butylated hydroxytoluene (BHT), propil galat $(\mathrm{PG})$ dan tert-butyl hydroquinone (TBHQ) selain untuk memenuhi kecukupan antioksidan tubuh, juga karena antioksidan sintetis memiliki sifat lebih stabil dalam bahan pangan dibandingkan antioksidan alami (Pristiadi, 2010). Namun akhir-akhir ini peneliti menemukan bahwa penggunaan antioksidan sintetis diduga dapat menjadi agen karsinogenik penyebab penyakit kanker dan tumor (Hernani dan Mono Raharjo, 2005) dan mempunyai efek toksik (Kikuzaki et al, 2002). Adanya kekhawatiran akan kemungkinan efek samping dari antioksidan sintetis ini menyebabkan antioksidan alami menjadi alternatif yang sangat dibutuhkan (Sunarti, 2005).

Salah satu sumber antioksidan alami yang banyak ditemui pada bagian tanaman terutama pada bunga dan buah salah satunya adalah antosianin (Jordheim, 2007). Menurut sentra Informasi IPTEK (2009), buah cengkodok berwarna ungu kemerahan diduga mengandung antosianin dan dapat diekstrak antosianinnya dengan cara ekstraksi menggunakan pelarut-pelarut yang bersifat polar karena sifat antosianin yang juga bersifat polar. Pada umumnya, dalam pengukuran antioksidan, pelarut etanol yang paling sering digunakan. Saati (2002) menjelaskan etanol umumnya digunakan dalam ekstraksi antosianin karena kepolarannya hampir sama dengan polaritas 
antosianin sehingga mudah melarutkan antosianin. Pengukuran aktivitas antioksidan perlu dilakukan untuk mengetahui seberapa besar potensi antioksidan dari bahan yang diperkirakan. Penelitian sebelumnya telah dilakukan oleh Kristiana, et al (2012), terhadap kadar total antosianin dan kapasitas antioksidan pada tanaman senggani (Melastoma malabathricum Auct. Non Linn) dengan variasi jenis pelarut, menghasilkan ekstrak terbaik dengan pelarut etanol dan asam sitrat.

Penelitian bertujuan untuk mengekstrak antosianin yang terkandung dalam buah cengkodok dengan 2 metode yaitu cara basah dan cara kering, untuk mencari perbandingan aktivitas antioksidan dari kedua metode dan menguji kestabilan aktivitas antioksidan serta kestabilan pigmen antosianinnya.

\section{Materi dan Metode}

Materi yang digunakan adalah buah cengkodok, sedangkan bahan kimia yang digunakan adalah etanol $70 \%$, metanol teknis, asam sitrat, akuades, gula pasir, asam cuka, $\mathrm{NaOH} 10 \%, \mathrm{HCl} 1,5 \mathrm{~N}$, dan 1,1-difenil-2pikrilhidrazil (DPPH). Peralatan yang digunakan adalah magnetic strirrer, beaker glass, hot plate, penangas air, corong, kertas saring, pompa vakum, mortar, saringan 100 mesh, oven, $\mathrm{pH}$ meter, rotary evaporator, dan spektrometer UV-Vis dan UV-1800 shimadzu.

Rancangan Percobaan yang digunakan dalam penelitian adalah Rancangan Acak Lengkap (RAL) dilakukan dalam dua tahap yaitu tahap pertama ekstraksi basah dan kering, kemudian ditentukan rendemen, total antosianin, dan aktivitas antioksidan. Tahap kedua yaitu sampel yang memiliki persentase antioksidan tertinggi digunakan sebagai sampel uji lanjutan stabilitas antioksidan dan stabilitas warna terhadap variasi $\mathrm{pH}$, kadar gula, dan suhu pemanasan.

\section{Metode}

Metode ekstraksi cara basah meliputi persiapan bahan, sortasi, penghancuran, penimbangan 60 gram, ekstraksi maserasi dengan pelarut etanol + asam sitrat 3\% dengan perbandingan bahan dan pelarut 1:4 (Kristiana et al, 2012) selama 24 jam suhu ruang sambil diaduk dengan stirrer secara kontinyu, dilanjutkan dengan penyaringan, maserasi dengan pelarut baru, penyaringan dengan pompa vakum, serta pemekatan yaitu menguapkan pelarut dengan penangas air suhu $60^{\circ} \mathrm{C}$ sehingga diperoleh ekstrak pigmen kental (Winarti dan Firdaus, 2010). Metode ekstraksi cara kering sama halnya dengan cara basah, namun sampel terlebih dahulu dikeringkan dengan oven suhu $40^{\circ} \mathrm{C}$, dibuat serbuk dengan cara diblender dan diayak dengan ayakan 100 mesh (Sunardi dan Kuncahyo, 2007).

\section{Rendemen, Total Antosianin, Aktivitas Antioksidan}

Rendemen Ekstrak Pigmen Antosianin diuji berdasarkan AOAC (1990) merupakan perbandingan antara berat produk setelah jadi dengan berat awal. Rendemen ditandai dengan hasil akhir dari serangkaian proses pengolahan. Rendemen dapat dihitung dengan pembagian antara berat akhir dibagi dengan berat awal dikalikan $100 \%$.
Total antosianin dianalisis dengan menggunakan metode yang digunakan oleh peneliti sebelumnya, yaitu Less, D.H dan Francis, F.J (1972) yang dimodifikasi. Sebanyak $0,5 \mathrm{ml}$ filtrat hasil ekstraksi diencerkan hingga $5 \mathrm{ml}$ dengan etanol 95\%: $\mathrm{HCl} 1,5 \mathrm{~N}(85: 15)$. Filtrat kemudian diukur absorbansinya dengan spektrofotometer pada panjang gelombang $535 \mathrm{~nm}$. Total antosianin (miligram per 100 gram sampel) dihitung dengan pembagian nilai absorbansi dikalikan faktor pengenceran dikalikan 100 dengan 98,2 kali berat sampel dalam gram:

Uji aktivitas antioksidan menggunakan metode 1,1-diphenyl-2-picrylhydrazyl (DPPH). Larutan DPPH konsentrasi $0,004 \%(\mathrm{~b} / \mathrm{v})$ dibuat dengan menimbang 2 mg kristal DPPH yang dilarutkan dalam metanol $50 \mathrm{ml}$. Larutan sampel dibuat dengan menimbang ekstrak sebanyak $10 \mathrm{mg}$ dan dilarutkan ke dalam $10 \mathrm{ml}$ metanol (konsentrasi 1000 ppm). Dipipet 2 ml larutan sampel ke dalam tabung reaksi, kemudian ditambahkan $4 \mathrm{ml}$ larutan DPPH. Dikocok hingga homogen. Campuran dibungkus dengan aluminium foil, kemudian diinkubasi dalam ruangan gelap pada suhu kamar selama 30 menit. Selanjutnya diukur absorbansinya pada panjang gelombang $517 \mathrm{~nm}$. Aktivitas antioksidan dinyatakan dalam bentuk persen yaitu: absorbansi kontrol kali absorbansi sampel dibagi dengan absorbansi kontrol dikalikan $100 \%$

\section{Stabilitas antioksidan}

Uji aktivitas antioksidan terhadap pengaruh $\mathrm{pH}$ dilakukan dengan menimbang $50 \mathrm{mg}$ ekstrak. Ekstrak dilarutkan dalam $50 \mathrm{ml}$ metanol (konsentrasi 1000 ppm) dan diukur $\mathrm{pH}$ nya. Ditakar masing-masing $10 \mathrm{ml}$ untuk 5 perlakuan dalam beaker glass $100 \mathrm{ml}$ dan ditambahkan asam asetat atau $\mathrm{NaOH} 10 \%$ untuk menurunkan atau menaikkan $\mathrm{pH}$ serta didiamkan selama 30 menit. Selanjutnya dipipet $2 \mathrm{ml}$ tiap-tiap larutan sampel ke dalam tabung reaksi dan ditambahkan $4 \mathrm{ml}$ larutan DPPH. Dikocok hingga homogen. Tabung reaksi dibungkus dengan aluminium foil, kemudian diinkubasi dalam ruang gelap selama 30 menit. Setelah itu masukkan larutan ke dalam kuvet dan ditera pada spektrofotometer dengan panjang gelombang $517 \mathrm{~nm}$. Uji aktivitas antioksidan terhadap pengaruh kadar gula dilakukan dengan membuat larutan gula dengan 3 perlakuan, yaitu kadar gula 10, 30 dan 50\% (masing-masing dalam $100 \mathrm{ml}$ akuades). Ditimbang $30 \mathrm{mg}$ ekstrak dan dilarutkan dalam $30 \mathrm{ml}$ metanol (konsentrasi 1.000 ppm). Larutan sampel tersebut ditakar masing-masing $10 \mathrm{ml}$ untuk 3 perlakuan dalam beaker glass $200 \mathrm{ml}$. Ditambahkan larutan gula untuk tiap perlakuan 10, 30 dan 50\% ke dalam masing-masing larutan sampel dan dikocok hingga homogen serta didiamkan selama 30 menit. Selanjutnya dipipet $2 \mathrm{ml}$ tiap-tiap larutan sampel ke dalam tabung reaksi dan ditambahkan $4 \mathrm{ml}$ larutan DPPH. Dikocok hingga homogen. Tabung reaksi dibungkus dengan aluminium foil, kemudian diinkubasi dalam ruang gelap selama 30 menit. Setelah itu masukkan larutan ke dalam kuvet dan ditera pada 
spektrofotometer dengan panjang gelombang $517 \mathrm{~nm}$ (Banerjee et al, 2005).

Uji aktivitas antioksidan terhadap pengaruh suhu pemanasan dilakukan dengan menimbang $40 \mathrm{mg}$ ekstrak dan dilarutkan dalam $40 \mathrm{ml}$ metanol. Larutan sampel tersebut ditakar masing-masing $10 \mathrm{ml}$ untuk perlakuan tanpa pemanasan, pemanasan suhu 40,60 dan $80^{\circ} \mathrm{C}$ dalam beaker glass $100 \mathrm{ml}$ dan ditutup dengan aluminium foil. Larutan sampel dipanaskan di atas penangas hot plate hingga tercapai suhu yang diharapkan. Kemudian didiamkan selama 30 menit. Selanjutnya dipipet $2 \mathrm{ml}$ tiap-tiap larutan sampel ke dalam tabung reaksi dan ditambahkan $4 \mathrm{ml}$ larutan DPPH. Dikocok hingga homogen. Tabung reaksi dibungkus dengan aluminium foil, kemudian diinkubasi dalam ruang gelap selama 30 menit. Setelah itu masukkan larutan ke dalam kuvet dan ditera pada spektrofotometer dengan panjang gelombang $517 \mathrm{~nm}$.

\section{Stabilitas Warna}

Uji stabilitas warna antosianin terhadap pengaruh $\mathrm{pH}$ dilakukan dengan menimbang $0,5 \mathrm{gr}$ ekstrak, dan dilarutkan ke dalam $1.000 \mathrm{ml}$ akuades (konsentrasi 500 ppm), kemudian larutan diukur pHnya. Ditakar $100 \mathrm{ml}$ larutan ekstrak ke dalam masing-masing beaker glass $100 \mathrm{ml}$, dan ditetesi asam asetat atau $\mathrm{NaOH} 10 \%$ untuk menurunkan atau menaikkan $\mathrm{pH}$ sehingga terbentuk larutan dengan $\mathrm{pH} 3,4,5,6,7,8$ dan 9. Setiap perlakuan diukur warnanya pada spektrofotometer dengan panjang gelombang $517 \mathrm{~nm}$ (Miksusanti, et al, 2012; Winarti, et al, 2008).

Pengujian stabilitas warna terhadap pengaruh kadar gula dilakukan dengan menimbang $0,05 \mathrm{gr}$ ekstrak dan membuat larutan gula dengan konsentrasi $10,20,30,40$ dan $50 \%$ dalam $100 \mathrm{ml}$ akuades. Kemudian melarutkan ekstrak ke dalam masing-masing larutan gula (konsentrasi 500 ppm). Setiap perlakuan diukur warnanya pada spektrofotometer dengan panjang gelombang $517 \mathrm{~nm}$. Pengujian stabilitas warna terhadap suhu pemanasan dilakukan dengan menimbang $0,5 \mathrm{gr}$ ekstrak dan dilarutkan dalam 1.000 $\mathrm{ml}$ akuades (konsentrasi 500 ppm). Ditakar $100 \mathrm{ml}$ ke dalam masing-masing beaker glass $100 \mathrm{ml}$ untuk perlakuan tanpa pemanasan, suhu pemanasan 40, 60 dan $80^{\circ} \mathrm{C}$. Kemudian setiap larutan dipanaskan di atas hot plate hingga tercapai suhu perlakuan, dan didiamkan selama 30 menit. Setiap perlakuan diukur warnanya pada spektrofotometer dengan panjang gelombang $517 \mathrm{~nm}$. Data yang telah diperoleh dianalisa dengan menggunakan Analisis Varian percobaan faktor tunggal dan dilanjutkan dengan Uji Jarak Ganda Duncan (Gomez, K.A and Gomez, A.A.,1995).

\section{Hasil dan Pembahasan}

Rendemen

Hasil pengujian ekstrak pigmen buah cengkodok dapat dilihat pada Tabel 1. Pada Tabel 1. menunjukkan adanya perbedaan hasil dari setiap perlakuan untuk mengekstraksi zat warna antosianin dari buah cengkodok. Ekstraksi cara basah memiliki rendemen lebih tinggi $(32,6142 \%)$ dibandingkan ekstraksi cara kering $(30,2563 \%)$. Pada ekstraksi cara basah tingkat kehalusan dan penghancuran bahan lebih tinggi dibandingkan dengan cara kering yang masih berupa serbuk. Semakin halus atau hancur bahan maka sel-sel pada bahan akan cepat rusak dan pecah sehingga pelarut mudah masuk ke dalam sel bahan dan antosianin mudah terekstraksi. Disamping itu, cara basah tidak melibatkan pengeringan sehingga tidak banyak material yang teruapkan. Harborne (1987) di dalam Lazuardi (2010) menyatakan bahwa struktur molekul yang makin sederhana menyebabkan porositas atau pori-pori bahan makin besar, sehingga pelarut makin mudah berdifusi ke dalam sel-sel bahan yang diekstraksi.

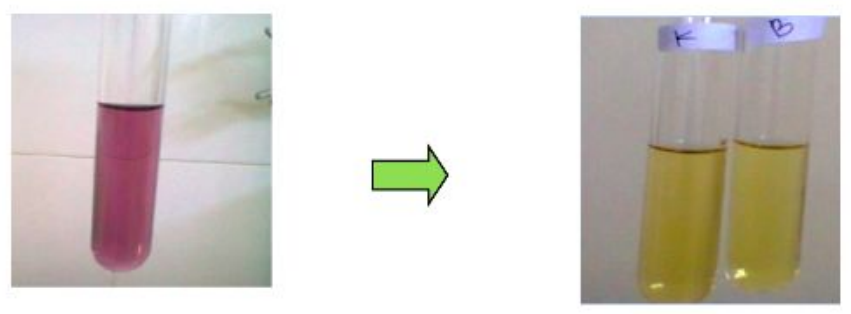

Gambar 1. Perubahan Warna Sampel

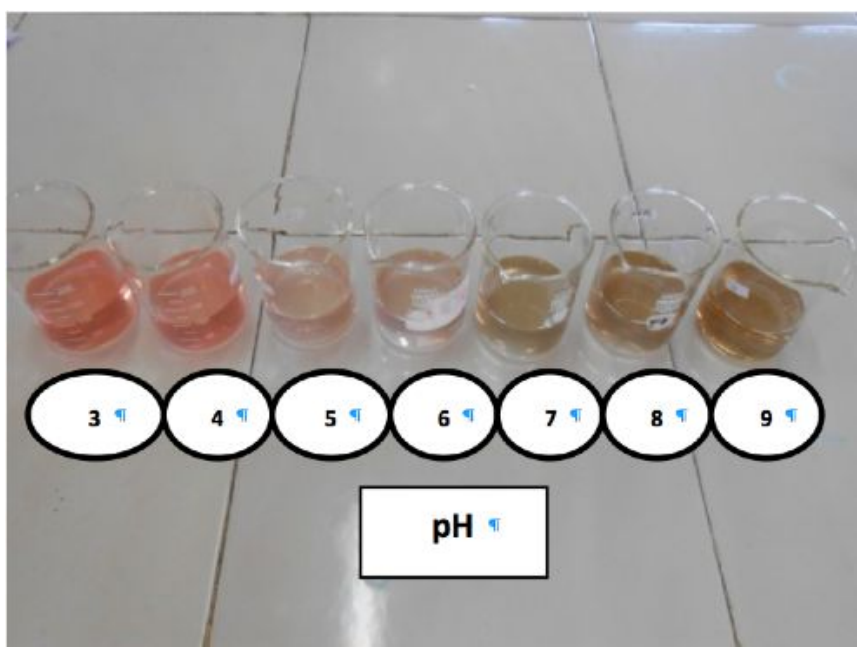

Gambar 2. Perubahan Warna Akibat Pengaruh pH

\section{Total Antosianin}

Antosianin adalah zat warna alami yang bersifat sebagai antioksidan yang terdapat dalam tumbuhtumbuhan dan merupakan senyawa turunan dari kation flavilium $\left(\mathrm{AH}^{+}\right)$(pembentuk warna merah) (Wibiani, 2010). Pada Tabel 1. menunjukkan bahwa total antosianin pada cara basah lebih tinggi dibandingkan cara kering yaitu sebanyak $33,3279 \mathrm{mg} / 100 \mathrm{gr}$ sampel. $\mathrm{Hal}$ ini dikarenakan cara basah tidak melibatkan panas secara langsung ke dalam bahan (buah cengkodok), sehingga antosianin yang terkandung tidak terdegradasi menjadi tak berwarna, dan terbaca dengan serapan yang lebih besar pada spektrofotometer (Fenema, 1996 dalam Lazuardi (2008). Selain itu menurut Arthey dan Ashurst (2001) dalam Wibiani (2010), degradasi antosianin dipengaruhi oleh temperatur. Aglikon antosianin yang mengalami pergeseran dengan urutan sebagai berikut: Quinoid (Biru) $\rightarrow$ Flavilium (merah) $\rightarrow$ Basa karbinol (tak berwarna) $\rightarrow$ Kalkon (tak berwarna). 


\section{Aktivitas antioksidan}

DPPH merupakan radikal sintetis yang diujikan kepada sampel yang diduga mengandung antioksidan (AH). Aktivitas antioksidan dari sampel yaitu dengan adanya donasi atau pemberian atom hidrogen $(H)$. Aktivitas ini ditandai dengan perubahan warna pada sampel yang ditambahan DPPH dari ungu menjadi kuning pucat dapat dilihat pada Gambar 1.

Diuji dalam konsentrasi 1000 ppm, aktivitas antioksidan pada cara basah $(95,2234 \%)$ lebih besar dibandingkan dengan cara kering $(90,5558 \%)$. Kontak panas pada proses pengeringan mempengaruhi rendahnya aktivitas antioksidan pada cara kering. Rendahnya aktivitas antioksidan ini sebanding dengan total antosianin, hal ini sejalan dengan penelitian Kristiana et al (2012) tentang Ektraksi Pigmen Antosianin Buah Senggani (Melastoma malabathricum Auct. Non Linn), dimana semakin besar nilai antosianin, semakin besar pula aktivitas antioksidannya. Panas ataupun cahaya dapat memicu pra oksidasi. Dengan kata lain, sampel telah mendonorkan atom $\mathrm{H}$ nya untuk membentuk hidroperoksida, sehingga daya reduksi terhadap DPPH semakin rendah (Kurniawati, 2007).

Tabel 1. Rata-rata Hasil Pengujian Ekstrak Pigmen Antosianin Buah Cengkodok

\begin{tabular}{cccc}
\hline $\begin{array}{r}\text { Perlakuan } \\
\text { Ekstraksi }\end{array}$ & \multicolumn{3}{c}{ Parameter Pengamatan } \\
\cline { 2 - 4 } & $\begin{array}{c}\text { Rendemen } \\
(\%)\end{array}$ & $\begin{array}{c}\text { Antosianin } \\
(\mathrm{mg} / 100 \mathrm{~g})\end{array}$ & $\begin{array}{c}\text { Aktivitas } \\
\text { Antioksidan } \\
(\%)\end{array}$ \\
\cline { 2 - 4 } Cara Basah & 32,6142 & 33,3279 & 95,2234 \\
Cara Kering & 30,2563 & 22,0516 & 90,5558 \\
\hline
\end{tabular}

Tabel 2. Rata-rata Aktivitas Antioksidan Ekstrak Buah Cengkodok pada Variasi $\mathrm{pH}$

\begin{tabular}{cc}
\hline Perlakuan & $\begin{array}{c}\text { Aktivitas Antioksidan } \\
(\%)\end{array}$ \\
\hline $\mathrm{pH} \mathrm{3}$ & $82,2898^{\mathrm{a}}$ \\
$\mathrm{pH} 4$ & $82,0358^{\mathrm{ab}}$ \\
$\mathrm{pH} 5$ & $81,5903^{\mathrm{abc}}$ \\
$\mathrm{pH} 6$ & $77,7195^{\mathrm{cd}}$ \\
$\mathrm{pH} 7$ & $76,7045^{\mathrm{d}}$ \\
\hline
\end{tabular}

Ket: Setiap rataan yang mempunyai huruf yang sama dinyatakan tidak berbeda nyata pada Uji Duncan taraf $5 \%$

Tabel 3. Rata-rata Aktivitas Antioksidan Ekstrak Buah Cengkodok pada Berbagai Konsentrasi Gula

\begin{tabular}{cc}
\hline Perlakuan & $\begin{array}{c}\text { Aktivitas Antioksidan } \\
(\%)\end{array}$ \\
\hline Kadar gula $10 \%$ & $89,4899^{\mathrm{a}}$ \\
Kadar gula $30 \%$ & $45,7179^{\mathrm{ab}}$ \\
Kadar gula 50 \% & $36,5479^{\mathrm{b}}$ \\
\hline
\end{tabular}

Ket: Setiap rataan yang mempunyai huruf yang sama dinyatakan tidak berbeda nyata pada Uji Duncan taraf 5\%

Tabel 4. Rata-rata Aktivitas Antioksidan Ekstrak Buah Cengkodok pada Berbagai Suhu Pemanasan

\begin{tabular}{cc}
\hline Perlakuan & $\begin{array}{c}\text { Aktivitas Antioksidan } \\
(\%)\end{array}$ \\
\hline Tanpa pemanasan & $95,2144^{\mathrm{a}}$ \\
Suhu $40^{\circ} \mathrm{C}$ & $79,8220^{\mathrm{b}}$ \\
Suhu $60^{\circ} \mathrm{C}$ & $79,3821^{\mathrm{b}}$ \\
Suhu $80^{\circ} \mathrm{C}$ & $70,2343^{\mathrm{c}}$
\end{tabular}

Ket: Setiap rataan yang mempunyai huruf yang sama dinyatakan tidak berbeda nyata pada Uji Duncan taraf $5 \%$

Variasi $\mathrm{pH}$ terhadap Stabilitas Antioksidan

Uji stabilitas antioksidan dilakukan pada ekstrak antosianin cara basah. Uji ini dilakukan untuk mengetahui pengaruh $\mathrm{pH}$, kadar gula, dan suhu pemanasan pada aktivitas antioksidan ekstrak antosianin buah cengkodok. Hasil pengamatan terhadap aktivitas antioksidan pada berbagai kondisi $\mathrm{pH}$ dapat dilihat pada Tabel 2. Data hasil pengamatan pada Tabel 2 menunjukkan bahwa terdapat berbeda nyata pada taraf $5 \%$ pada perlakuan $\mathrm{pH} 3,6$ dan 7 . Semakin tinggi nilai $\mathrm{pH}$ maka aktivitas antioksidan semakin menurun. Antioksidan berfungsi sebagai donor hirogen untuk menstabilkan senyawa radikal. Menurut Tensiska (2001), pada $\mathrm{pH}$ rendah, densitas ion hidrogen dalam medium meningkat sehingga menekan pelepasan ion hidrogen untuk meredam radikal bebas.

\section{Kadar Gula terhadap Stabilitas Antioksidan}

Hasil pengamatan aktivitas antioksidan pigmen antosianin pada berbagai perlakuan kadar gula dapat dilihat pada Tabel 3. Aktivitas antioksidan semakin menurun seiring dengan meningkatnya kadar gula dalam larutan. Berdasarkan uji Duncan, aktivitas antioksidan pada perlakuan kadar gula $10 \%$ berbeda nyata dengan perlakuan kadar gula $50 \%$. Hal ini terjadi karena antosianin mengalami degradasi dalam larutan gula akibat bertambahnya gugus hidroksil pada larutan yang mempengaruhi struktur pigmen antosianin (Winarno, 2004). Hal ini menyebabkan gugus metilasi dan atom $\mathrm{H}$ semakin berkurang. Berkurangnya atom $\mathrm{H}$ akan menurunkan aktivitas antioksidan sebagai pendonor hidrogen pada radikal bebas.

\section{Suhu Pemanasan terhadap Stabilitas Antioksidan}

Hasil pengamatan pengaruh suhu pemanasan terhadap aktivitas antioksidan dapat dilihat pada Tabel 4. Antioksidan sangat tidak stabil pada suhu tinggi. Penurunan aktivitas antioksidan terjadi seiring naiknya suhu pemanasan. Semakin tinggi suhu pemanasan, maka semakin rendah aktivitas antioksidan yang dihasilkan. Berdasarkan Uji Duncan, perlakuan tanpa pemanasan berbeda nyata dengan perlakuan suhu 40 , 60 dan $80^{\circ} \mathrm{C}$. Sedangkan perlakuan suhu 40 dan $60^{\circ} \mathrm{C}$ tidak berbeda nyata. Menurut Hermawan, et al, (2010), suhu mengakibatkan degradasi antosianin, yaitu penguraian struktur dari kation flavilium menjadi kalkon atau tak berwarna. Disamping itu, semakin meningkatnya suhu pemanasan semakin memicu terjadinya reaksi oksidasi pada ekstrak bahan yang akan diuji kapasitas antioksidannya. Suhu atau temperatur yang tinggi merupakan katalisator bagi reaksi oksidasi (Winarno, 2004).

\section{Variasi $\mathrm{pH}$ terhadap Stabilitas Warna}

Uji stabilitas warna merupakan uji lanjutan yang dilakukan pada ekstrak yang memiliki aktivitas antioksidan tinggi yaitu ekstraksi dengan cara basah. Uji ini dilakukan untuk mengamati pengaruh $\mathrm{pH}$, kadar gula dan suhu pemanasan terhadap warna antosianin ekstrak buah cengkodok.

Hasil pengamatan absorbansi stabilitas pigmen antosianin dapat dilihat pada Tabel 5. Antosianin adalah senyawa yang bersifat amfoter, yaitu memiliki kemampuan untuk bereaksi baik dengan asam maupun 
dalam basa. Tabel 5 menunjukkan bahwa $\mathrm{pH}$ mempengaruhi kestabilan warna ekstrak buah cengkodok. Antosianin lebih stabil pada kondisi asam dibandingkan kondisi basa. Pada Gambar 2 Warna merah pada larutan semakin memudar dan menghilang seiring dengan naiknya $\mathrm{pH}$. Menurut De Man (1997) dalam buku Kimia Makanan, kondisi basa akan mengakibatkan peningkatan jumlah gugus hidroksil yang cenderung menguatkan warna menjadi lebih berona biru. Dalam larutan terdapat kesetimbangan antosianin antara kation $\mathrm{R}^{+}$yang berwarna atau garam oksonium dan peudobasa $\mathrm{ROH}$ yang tidak berwarna, tergantung pada $\mathrm{pH}$. Jika $\mathrm{pH}$ naik, lebih banyak pseudobasa $\mathrm{ROH}$ yang terbentuk dan menyebabkan warna makin lemah (De Man, 1997).

Tabel 5. Rata-rata Nilai Absorbansi Warna Ekstrak Buah Cengkodok Terhadap Pengaruh $\mathrm{pH}$

\begin{tabular}{ccc}
\hline Perlakuan & Kenampakan Warna & $\begin{array}{c}\text { Absorbansi } \\
(\lambda=517 \mathrm{~nm})\end{array}$ \\
\hline pH 3 & Merah muda & 13 \\
pH 4 & Merah muda & 11 \\
pH 5 & Merah muda mulai & 10 \\
& pudar & \\
pH 6 & Pudar (bening) & 8 \\
pH 7 & Kuning pucat & 11 \\
pH 8 & Kuning & 14 \\
pH 9 & Kuning pekat kebiruan & 15 \\
\hline
\end{tabular}

Tabel 6. Rata-rata Nilai Absorbansi Warna Ekstrak Buah Cengkodok Terhadap Pengaruh Kadar Gula

\begin{tabular}{cc}
\hline Perlakuan & $\begin{array}{c}\text { Absorbansi } \\
(\lambda=517 \mathrm{~nm})\end{array}$ \\
\hline Kadar gula 10\% & 16 \\
Kadar gula 20\% & 15 \\
Kadar gula 30\% & 14 \\
Kadar gula 40\% & 14 \\
Kadar gula 50\% & 12 \\
\hline
\end{tabular}

Tabel 7. Rata-rata Nilai Absorbansi Warna Antosianin Buah Cengkodok Terhadap Pengaruh Suhu Pemanasan

\begin{tabular}{cc} 
Perlakuan & $\begin{array}{c}\text { Absorbansi } \\
(\lambda=517 \mathrm{~nm})\end{array}$ \\
\hline Tanpa pemanasan & 14 \\
Suhu $40^{\circ} \mathrm{C}$ & 13 \\
Suhu $60^{\circ} \mathrm{C}$ & 12 \\
Suhu $80^{\circ} \mathrm{C}$ & 10 \\
\hline
\end{tabular}

Kadar Gula terhadap Stabilitas Warna

Hasil pengamatan absorbansi dari pengaruh kadar gula terhadap pigmen antosianin ekstrak buah cengkodok dapat dilihat pada Tabel 6. Berdasarkan nilai absorbansi yang dihasilkan pada Tabel 6, kadar gula mempengaruhi kestabilan warna ekstrak buah cengkodok. Semakin tinggi kadar gula, maka semakin rendah nilai absorbansinya. Larutan gula dapat mereduksi warna dari antosianin sehingga menyebabkan deteriorasi (pemburukan warna) pigmen antosianin dan memberikan browning (pencoklatan) (Nikkhah, et. al, 2007, dalam Lazuardi, 2010).

\section{Suhu Pemanasan terhadap Stabilitas Warna}

Hasil pengamatan absorbansi dari pengaruh suhu pemanasan terhadap pigmen antosianin ekstrak buah cengkodok dapat dilihat pada Tabel 7. Hasil pengamatan nilai absorbansi warna antosianin menunjukkan bahwa suhu mempengaruhi kestabilan warna ekstrak buah cengkodok. Terjadi penurunan nilai absorbansi seiring dengan meningkatnya suhu pemanasan antosianin. Winarti, et al (2008), dalam stabilitas pigmen ubi jalar ungu menyatakan semakin tinggi suhu maka absorbansi atau stabilitas warna semakin rendah. Ekstrak zat warna yang diperoleh dari ubi jalar ungu bersifat tidak stabil terhadap pemanasan. Penurunan absorbansi ini disebabkan karena terjadinya kerusakan gugus kromofor pigmen dan menurunkan kuantitas kation flavilium yang menyebabkan pemucatan warna (Nailufar, et al, 2012).

\section{Kesimpulan}

Hasil terbaik diperoleh dari ekstraksi dengan cara basah, dengan rendemen $32,6142 \%$, total antosianin $33,3279 \mathrm{mg} / 100 \mathrm{gr}$ bahan, dan aktivitas antioksidan 95,2234\% (dalam konsentrasi 1000 ppm). Aktivitas antioksidan pigmen antosianin mengalami penurunan seiring dengan meningkatnya nilai $\mathrm{pH}$, kadar gula, dan suhu pemanasan. Stabilitas warna pigmen antosianin mengalami penurunan absorbansi seiring dengan meningkatnya nilai $\mathrm{pH}$, kadar gula, dan suhu pemanasan.

\section{Daftar Pustaka}

AOAC. 1990. Official Methods of Analysis. Washington: Association of Official Analytical Chemist.

Chang, L Yen, Wen Jhe, Huang, S.C. and Duh, Pirder. 2002. Antioxidant Activity of Sesame Coat Food Chemistry $78: 347-354$.

De Man, J. M. 1997. Kimia Makanan, Edisi kedua. Penerjemah Kosasih Padmawinata. ITB, Bandung.

Gomez, K. A. dan A. A. Gomez. 1995. Prosedur Statistik untuk Penelitian Pertanian. (Terjemahan). E. Syamsudin dan J. S. Baharsjah. UI Press. Jakarta. 698 hal.

Hartanto, Hondy. 2012. Identifikasi Potensi Antioksidan Minuman Cokelat dari Kakao Lindak (Theobroma Cacao L.) dengan Berbagai Cara Preparasi Metode Radikal Bebas DPPH. Skripsi. Universitas Katolik Widya Mandala, Surabaya.

Hermawan, R., Hayati, E.K., Budi, U.S. 2010. Effect of Temperature, $\mathrm{PH}$ on Total Concentration and Color Stability of Anthocyanins Compound Extract Roselle (Calyx). Jurnal Tekno Pangan. Universitas Maulana Malik Ibrahim, Malang.

Hernani dan Mono Raharjo. 2005. Tanaman Berkhasiat Antioksidan. Penerbit Swadaya, Jakarta.

Jordheim, M. 2007. Isolation, Identifikation and Poperties of Pyranoanthocyanins and Anthocyanin Form. Disertasi. Di dalam Supiyanti, W., Wulansari, E.D., dan Kusmita, L. Uji Aktivitas Antiosidan dan Penentuan Kandungan Antosianin Total Kulit Buah Manggis (Garcinia mangostana L.). Majalah Obat Tradisional, 15 (2), 64-70.

Kikuzaki, H. And K. Nakatani. 1993. Antioxidant Effect of Some Ginger Constituents. Journal Food Science 58: 1407-1410. 
Kristiana, H. D., Ariviani, S., dan Khasanah, L. U. Jurnal Ilmu dan Teknologi Pangan "Ekstraksi Pigmen Antosianin Buah Senggani (Melastoma malabathricum Auct. Non Linn) dengan Variasi Pelarut". Universitas Sebelas Maret, Surakarta.

Kurniawati, Maya. 2007. Penentuan Formula Antioksidan Untuk menghambat Ketengikan pada Bumbu Ayam Goreng Kalasan Selama Satu Bulan. Skripsi. IPB, Bogor.

Lazuardi, R. M. N. 2010. Mempelajari Ekstraksi Pigmen Antosianin dari Kulit Buah Manggis (Garcinia mangostana L.) dengan Berbagai Jenis Pelarut. Tugas Akhir. Universitas Pasundan, Bandung.

Lees, D.H. dan Francis, F.J. 1972. Analysis of anthocyanins. Di dalam Anthocyanins as Food Colors. Markakis, P. (ed). Academic Press, NewYork.

Miksusanti, Elvita, dan Hotdelina, S. 2012. Aktivitas Antioksidan Dan Sifat Kestabilan Warna Campuran Ekstrak Etil Asetat Buah Manggis (garcinia mangostana, L) dan Kayu Secang (Caesalpinia sappan L).Jurnal Penelitian Sains. 15 (2):60-69

Nailufar, A.A, Basito, dan Anam, C. 2012. Kajian Karakteristk Ketan Hitam Pada Berbagai Jenis Pengemas. Jurnal Tekno Sains Pangan Vol.1.

Pristiadi, 2010. Kajian Komparatif Aktivitas Antioksidan Formula pEngawaet Alami Ekstrak Kecombrang (Nicolaia speciosa Horan) dan Pola Pemisahan Kromatografis Ekstrak Bagian-bagian Tanaman Kecombrang. Jurnal Program Pasca Sarjana. Universitas Jenderal Soedirman, Purwokerto.

Saati, E. A. 2002. Potensi Bunga Pacar Air (Impatiens Balsamina Linn.) Sebagai Pewarna Alami pada Produk Minuman. Majalah Tropika Vol. 10 (2).
Sentra Informasi IPTEK, 2009. Senggani (melastoma candidum D. Don. http://www.iptek.net.id/ind/pd_tanobat/view.php? $\mathrm{mnu}=2 \& i d=156$. Diakses pada tanggal 7 Juli 2013.

Suhartono, E., Fujiati, Aflanie, I. 2002. Oxygen Toxicity by Radiation and Effect of Glutamic Piruvat Transamine (GPT) Activity Rat Plasma After Vitamin C Treatmen. Diajukan pada Internatinal Seminar on Enviromental Chemistry and Toxicology, Yogyakarta.

Sunardi dan Kuncahyo. 2007. Uji Aktivitas Antioksidan Ekstrak Belimbing Wuluh (Averrhoa bilimbi, L.) terhadap 1,1-Diphenyl-2-picdrylhidrazyl (DPPH). Universitas Setia Budi, Yogyakarta.

Sunarti, T. 2005. Aktivitas Antioksidan Penangkap Radikal Bebas Beberapa Kecambah dari Biji Tanaman Familia Papilionacecae. Jurnal farmasi Indonesia 2 (2).

Tensiska, 2001. Aktivitas Antioksidan Ekstrak Buah Andaliman Dalam Beberapa Sistem Pangan dan Kestabilan Aktivitasnya dalam Suhu dan $\mathrm{pH}$. Tesis. IPB, Bogor.

Wibiani, 2010. Ekstraksi Antosianin Bunga Rosella dan Identifikasi Senyawanya. http://lib.uinmalang.ac.id/thesis/fullchapter/04530008-santiwibiani.ps.Jurnal Tekno Pangan Vol.12.

Winarno, F. G. 2004. Kimia Pangan dan Gizi. Gramedia Pustaka Utama, Jakarta.

Winarti, S., dan Firdaus, A. 2008. Stabilitas Warna Merah Ekstrak Bunga Rosela Untuk Pewarna Makanan dan Minuman. Jurnal Teknologi Pertanian Vol.11 (2):87 - 93. 